\title{
The ECHR and the Essence of Fundamental Rights: Searching for Sugar in Hot Milk?
}

\author{
Sébastien Van Drooghenbroeck* and Cecilia Rizcallah**
}

(Received 01 May 2019; accepted 30 May 2019)

\begin{abstract}
The concept of the "essence" - as well as the related concepts of "substance" or "core" - of fundamental rights is absent from the text of the European Convention on Human Rights (ECHR), but regularly appears in the case law of the European Court of Human Rights (ECtHR) since the Belgian Linguistic case of 1968. Yet, fifty years after its explicit emergence in the Convention's legal order, it must be observed that a clear understanding of this concept and of its practical utility is still lacking. Indeed, the idea of the essence of fundamental rights has never been clearly defined in its case law, which remains essentially pragmatic and unprincipled in this field. This Article will therefore attempt to remedy this shortcoming by sketching out the different functions assigned to the concepts of the essence, substance, and core of rights in the ECtHR's case law. It is postulated that the concepts of the essence, substance, and core of fundamental rights are invoked for three different types of purposes. First, the concepts of the essence, substance, and core areapparently at least—used by the ECtHR to fix the "limit on the limits," for example, the inalienable part of fundamental rights safeguarded from any possible restriction. Second, this concept has been a vehicle for expanding the Convention's sphere of protection for the purposes of guaranteeing its effectiveness. Third, the concepts of the essence, substance, and core of fundamental rights also constitute a "reviewing tool" used by the Court to determine the intensity of the States' obligations on the basis of a prioritization among a series of values at stake. Although these three different functions can be identified on paper, the practical usefulness, workability, and desirability of the concepts of the essence, substance, and core will be questioned.
\end{abstract}

Keywords: Essence; substance; core; European Court of Human Rights (ECHR); fundamental rights

\section{A. Introduction}

Michel Colucci_-alias Coluche_-a well-known French comedian, once said: "Dieu, c'est comme le sucre dans le lait chaud. Il est partout et on ne Le voit pas ... Et plus on Le cherche, moins on Le trouve." ("God is like sugar in hot milk. Everywhere but invisible ... And the more you search for Him the less you find Him."). ${ }^{1}$ The same observation could be made about the concept of the essence of fundamental rights, including in the European Convention on Human Rights.

The concept of the "essence" and related concepts such as the "substance" or the "[very hard] core" of fundamental rights have not been expressly enshrined in the text of the European Convention on Human Rights (hereinafter the "ECHR" or "Convention"). It emerged in the case law of the

\footnotetext{
${ }^{\star}$ Vice-Rector and Professor at the Law Faculty of the Université Saint-Louis-Bruxelles, Assessor at the Council of State, Belgium.

${ }^{* *}$ Research Fellow at the Belgian National Fund for Scientific Research (F.R.S. - FNRS) affiliated both to the Université Saint-Louis-Bruxelles and the Université libre de Bruxelles.

${ }^{1}$ Coluche, Pensées et anecdotes [Thoughts And Anecdotes] (1995).
} 
European Court of Human Rights (hereinafter, the "ECtHR" or "the Court") in the Court's 1968 Belgian Linguistic Case judgment, where it declared that:

The right to education guaranteed by the first sentence of Article 2 of the Protocol (P1-2) by its very nature calls for regulation by the State, regulation which may vary in time and place according to the needs and resources of the community and of individuals. It goes without saying that such regulation must never injure the substance of the right to education nor conflict with other rights enshrined in the Convention. ${ }^{2}$ (emphasis added)

Although it has been relied upon a number of times since first adopted by the ECtHR, the idea of the essence, core, and substance of fundamental rights has, however, never been explicitly defined and explained by the judgments of the Court, which remain essentially pragmatic and unprincipled on this question. ${ }^{3}$ Furthermore, the absence of a clear definition of this concept is observed in the relevant literature. In 1986, Eissen already stressed that we should not overestimate the scope of this notion because of the lack of consistency of the case law related to this question. ${ }^{4}$ Thirty years later, Rouzière-Beaulieu reached a similar conclusion in her $\mathrm{PhD}$ thesis focused on the ECtHR's protection of the core of fundamental rights by commenting on the "highly confused" nature of the case law on this matter. ${ }^{5}$

The separate dissenting opinions of Judges Sajo ${ }^{6}$ and Serighides ${ }^{7}$ in Regner v. The Czech Republic and of Judge Wojtyczek in Nä̈t-Liman v. Switzerland ${ }^{8}$ additionally point out-if still necessary - the uncertainties raised by these concepts, notably regarding their definition and function, and the ensuing urgency of an in-depth reflection in this field.

This Special Issue essentially reflects on the essence of fundamental rights in the EU. Still, addressing this question calls for particular attention to be paid to the corresponding concept in the ECHR. In addition to being at the heart of the European fundamental rights architecture, the ECHR is indeed explicitly recognized as a source of the EU fundamental rights protection since its outset. ${ }^{9}$ The EU Charter of Fundamental Rights in this sense explicitly enshrines that the rights it contains that correspond to rights guaranteed by the ECHR should receive the same scope of those laid down by the Convention. ${ }^{10}$ Moreover, nothing in the Charter shall, according to its wording, be interpreted as restricting or adversely affecting fundamental freedoms as recognized by the Convention. ${ }^{11}$ The analysis of the case law of the ECHR therefore constitutes, in our view, a necessary step of this collective issue focusing on the essence of fundamental rights in EU law. Taking note of these observations, this Article will attempt to shed some light on the different functions assigned to the concept in question in the ECHR system.

\footnotetext{
${ }^{2}$ Case "Relating to Certain Aspects of the Laws on the Use of Languages in Education in Belgium" v. Belgium, App. Nos. 1474/62, 1677/62,1691/62, 1769/63, 1994/63, 2126/64, para. 5 (July 23, 1968) [hereinafter The Belgian Linguistic Case] (emphasis added), http://hudoc.echr.coe.int/eng?i=001-57525.

${ }^{3}$ See, e.g., Julian Rivers, Proportionality and Variable Intensity of Review, 65 CAMBRIDGE L. J. 174 (2006); Maja Brkan, In Search of the Concept of Essence of EU Fundamental Rights Through the Prism of Data Privacy 10 (Maastricht Faculty of Law, Working Paper No. 01, 2017); Sébastien VAn Drooghenbroeck, La Proportionnalité dans le droit de La CONVENTION EUROPÉENNE DES DROITS DE L'HOMME 351 (2001).

${ }^{4}$ Marc-André Eissen, La Cour européenne des droits de l'homme, REvUE DE DROIT PUBLIC 1585 (1986).

${ }^{5} \mathrm{See}$ O. Rouzière-Beaulieu, La protection de la substance du droit par la Cour européenne des droits de l'Homme 309 (Sept. 2017) (unpublished Ph.D. thesis, Université de Montpellier).

${ }^{6}$ Regner v. The Czech Republic, App. No. 35289/11 (Sept. 19, 2017) (Sajó, J., dissenting), http://hudoc.echr.coe.int/eng? $\mathrm{i}=001-177299$.

${ }^{7} I d$. (Serghides, J., dissenting).

${ }^{8}$ Naït-Liman v. Switzerland, App. No. 51357/07 (Mar. 15, 2018) (Wojtyczek, J., dissenting), http://hudoc.echr.coe.int/eng? $\mathrm{i}=001-181789$.

${ }^{9}$ ECJ, Case 4/73, Nold KG v. Comm'n, ECLI:EU:C:1974:51, Judgment of 14 May, 1974, para. 12.

${ }^{10}$ Charter of Fundamental Rights of the European Union, Dec. 18, 2000, 2000 O.J. (C 364) art. 52, 33 [hereinafter CFREU].

${ }^{11} I d$. art. 53.
} 
At first glance, the idea of "essence/core/substance" evokes the specific importance of a prerogative and, as a corollary, the severe character of its limitation. Indeed, the "essence," "substance," and "core" of a right or a protection refers to its quiddity - to the elements without which this right or protection ceases to be itself, ceases to be "authentic," and, thereby ceases to present any value for its beneficiaries. A specific semantic field-a word cloud-is consequently immediately invoked. Positively, the ideas of fundamentality, obviousness, radicalism, and the categorical imperative come to mind. Negatively, the ideas of denial, annihilation, destruction, or less radically, of wilting, tampering, and the loss of meaning and interest emerge. The difference between what does and what does not belong to the "essence/core/substance" of rights consequently refers to the idea that these rights encompass components of varying importance.

Defined in this way, the gradation in weight of these elements seems to perform three main purposes in the case law of the ECtHR. First, the concept of the essence of fundamental rights or related concepts seem to play a role in the scrutiny of restrictions upon human rights. As recalled by Judge Wojticzek in his above-mentioned separate opinion, ${ }^{12}$ this function, which is most classically demonstrated by the notion of the essence of fundamental rights, finds its roots in German Basic Law. Its Article 19(2) provides that "in no case may a basic right be infringed upon its essential content." 13 The references to the cores of fundamental rights in the early case law of the EctHR seems, in a similar way, grounded on the purported existence of inalienable parts of rights and freedoms which may never, under any circumstances, be limited. ${ }^{14}$ The respect of the core of the restricted rights seems therefore to constitute a kind of untouchable "limit to the limit," whose respect constitutes a sine qua non condition of the validity of limitations upon fundamental freedoms.

Besides this traditional role in framing admissible limitations upon rights and freedoms, the concept of the substance/core/essence of fundamental rights also appears to endorse two other functions in the case law of the EctHR-more or less close to the first one, but nonetheless distinct. On the one hand, this concept seems to constitute a vehicle for expanding the Convention's sphere of protection (Schutzbereich) for the purposes of guaranteeing its practical utility, or effet utile. On the other hand, the idea of the essence/substance/core of fundamental rights seems to constitute a "reviewing tool" used by the Court to establish a prioritization among different values when it is so required in its assessment of a case.

Although these three different functions can be identified "on paper," the practical usefulness, workability, and desirability of the concepts of the essence/substance/core will be questioned. The array of difficulties it raises are indeed numerous and, it seems that as when looking for sugar in hot milk, the more you search for the essence of fundamental rights, the less likely you will be to find it.

Acknowledging the theoretical necessity of the concept of the essence of fundamental rights in the ECHR, this Article will nevertheless highlight its elusive character. It will moreover observe that it is subject to a certain "overwork," which adversely affects its intelligibility. This Article therefore advocates for a rationalization and, as a consequence, a decrease of the use of notion of "essence/substance/core" of fundamental rights by the ECtHR.

In support of this conclusion, this Article will analyze the different functions assigned to the idea of the essence/core/substance of rights in the ECHR legal order and the difficulties it causes. After examining its classical role of condition for the validity of limitations upon fundamental freedoms, ${ }^{15}$ this Article will analyze how the concept of essence has played a role in expanding

\footnotetext{
${ }^{12}$ Nä̈t-Liman, App. No. 51357/07.

${ }^{13}$ Gerhard van der Schyff, Cutting to the Core of Conflicting Rights: the Question of Inalienable Cores in Comparative Perspective, in Conflicts Between Human Rights 132 (Eva Brems ed., 2008).

${ }^{14} I d$. at 131.

${ }^{15}$ See infra Part B.
} 
the Convention's sphere of protection (Schutzbereich). ${ }^{16}$ Finally, this Article will study the way in which the ECtHR uses this notion as a technique for prioritizing values ${ }^{17}$.

\section{B. The Essence of Fundamental Rights: Limit to Fundamental Rights' Restrictions}

As underlined in the introduction, the classical assignment given to the notions of essence/core/ substance of rights concern the admissibility of fundamental rights restrictions, and, more specifically, the a priori definition of categorical prohibitions, unable to overcome a proportionality operation. The essence/substance/core of a fundamental right should be respected under any circumstances and its infringement should be unjustifiable: It constitutes the "limit to the limits" ("Ondergrens"18). From a theoretical point of view, the existence of such a "limit on the limits" in the ECHR axiomatic is indisputable and several "orthodox" landmark rulings of the ECtHR confirm this observation. ${ }^{19}$ Tested by the practice, however, these landmark rulings do not keep their promises and the ECtHR case law release numerous heterodox figures: The "limit of the limits" does not appear, or worse, is presented as being without limits. In correlation with this factor of perplexity, the difficulty to identify - in an orthodox pattern — what belongs to the essence/substance/core of fundamental rights must, moreover, be observed. ${ }^{20}$

\section{From Theory}

The most classical and widespread use of the notions of essence/core/substance of rights is, at least theoretically, to fix the "limit of the limits"- the inalienable part of fundamental rights which is denied any possible restriction. In fact, Judge Wojtyczek in his partly dissenting opinion in the recent Naït-Liman $v$. Switzerland judgment ${ }^{21}$ recalled that this function originally finds its roots in the German Basic Law which provides, in Article 19(2), that "in no case may a basic right be infringed upon its essential content." 22 The same assumption has later been enshrined in other national constitutions including, to name but a few, the Constitution of Switzerland, ${ }^{23}$ Portugal, ${ }^{24}$ Spain, ${ }^{25}$ and Turkey ${ }^{26}$; and also, in the EU Charter of Fundamental Rights. ${ }^{27}$ At first glance, these provisions suggest the following implications: A restriction made to a fundamental right which is not absolute will be considered admissible only if first, it respects the essence/substance/core of the right and, second, if it is provided by the law, pursues a legitimate aim, and respects the principle of proportionality. Accordingly, there should be unjustifiable limitations per se, even in relation to the rights that are not absolute categorical imperatives.

The existence of such a "limit to the limits" is, as we attempted to demonstrate in previous writings, ${ }^{28}$ a logical implication of the ECHR protection system. Indeed, as stressed by Judge

\footnotetext{
${ }^{16}$ See infra Part C.

${ }^{17}$ See infra Part D.

${ }^{18}$ JanneKe Gerards, EVRM Algemene Beginselen 167 (2011).

${ }^{19}$ See infra Part B(I).

${ }^{20}$ See infra Part B(II).

${ }^{21}$ Naït-Liman, App. No. 51357/07.

${ }^{22}$ van der Schyff, supra note 13, at 132.

${ }^{23}$ Bundesverfassung [BV] [CONSTItUtion] Apr. 18, 1999, SR 101, art. 36 (Switz.).

${ }^{24}$ Constitution of the Portuguese Republic, Apr. 25, 1974, art. 18(3).

${ }^{25}$ C.E., B.O.E. n. 311, Dec. 29, 1978, art. 53.1 (Spain).

${ }^{26}$ Türkiye CumhuriYeti ANAyasasi [Constitution] Nov. 7, 1982, art. 13 (Turk.).

${ }^{27} \mathrm{CFREU}$, supra note 10 , art. $52, \$ 1$. On this provision and the notion of essential content in the EU Charter of fundamental rights, see Sébastien Van Drooghenbroeck \& Cecilia Rizcallah, Article 52, in LA Charte Des Droits FOndamentaux DE L'Union Européenne CoMmentaire ARTiCle PAR ARTiCle 1083 (2017).

${ }^{28}$ See VAN DrooghenbroecK, supra note 3, at 377.
} 
Serghides in the recent Regner $v$. Czech Republic case, ${ }^{29}$ the absolute protection of the essence of fundamental rights can be derived from Article 17 of the Convention. To quote the Judge:

Under no circumstances is the role of an exception to a right under the Convention to render the right ineffective, still less to extinguish it, and no one, including the State, can invoke an exception in order to destroy a right. This is prohibited by Article 17 of the Convention". According to this provision, "nothing in this Convention may be interpreted as implying for any State, group or person any right to engage in any activity or perform any act aimed at the destruction of any of the rights and freedoms set forth herein or at their limitation to a greater extent than is provided for in the Convention. ${ }^{30}$

Yet, even if it is usually invoked in relation to the prohibition of abuse of rights committed by individuals, this provision also addresses States and thus precludes them from relying upon the fundamental rights' restrictions scheme ${ }^{31}$ in order to "destroy" these rights. ${ }^{32}$

From a theoretical point of view, it can even be submitted that the existence of an inalienable core of fundamental rights is an indispensable component of the fundamental rights' restriction framework as organized by the Convention. The search for the right balance among the interests at stake, which is inherent in the ECHR system, is indeed not neutral. ${ }^{33}$ As a matter of fact, the concern of safeguarding public order is not sought for itself, but precisely to guarantee the effectiveness of fundamental rights. ${ }^{34}$ Yet, acknowledging the fact that the safeguarding of public order has as a deep purpose the preservation of fundamental rights logically entails the rejection of fundamental rights restrictions leading to their destruction. ${ }^{35}$ The ECHR system thus-at least theoretically-permits limitations only in so far that they do not alter the very substance of the fundamental rights it protects. ${ }^{36}$

The notion was rapidly taken over by the case law of the ECtHR, initially mainly in relation to rights to which the text of the Convention is not expressly devoted, such as the right to educa-

\footnotetext{
${ }^{29}$ This judge moreover considers that Article 1 of the Convention itself provides for a foundation to the prohibition to infringe the substance of fundamental rights. According to him, it follows from the wording of Article 1 of the Convention, which entrusts the members States with an obligation to secure 'to everyone within their jurisdiction the rights and freedoms defined in Section 1 of this Convention', and particularly from the phrase 'defined in', that the determination of the ambit of the rights and freedoms is exclusively and exhaustively made in Section 1 (and, of course, the additional Articles in the Protocols). It is not the aim of an express exception to a right provided in the Convention to intervene with its core or essence; its aim is rather to limit or restrict the realisation of that right in certain cases, by following the proportionality test. Two legal Latin maxims are relevant in this respect: exceptio probat regulam, meaning 'an exception proves the rule'; exceptio que firmat legem, exponit legem, meaning 'an exception which confirms the law, expounds the law'. On the other hand, an absolute or blanket exception or restriction or ban goes right to the core of a right. So, it cannot be said that it confirms or expounds the right, but it merely annihilates it and renders it ineffective by removing the foundation on which it lies. Here the general Latin maxim sublato fundamento cadit opus, meaning 'remove the foundation, the work falls' may also be relevant. Were the proceedings criminal rather than civil or administrative, such a blanket and absolute restriction would probably violate the presumption of a person's innocence.

Regner, App. No. 35289/11 (Serghides, J., partly dissenting) (internal citations omitted).

${ }^{30}$ Id. at para. 50 .

${ }^{31}$ Notably provided by $\$ 2$ of the Convention's provisions.

${ }^{32}$ See Van Drooghenbroeck, supra note 3, at 528. See also Navalnyy v. Russia, App. No. 29580/12 (Nov. 15, 2018) (Pejchal, Dedov, Ravarani, Eicke \& Paczolay, JJ., partly dissenting), http://hudoc.echr.coe.int/eng?i=001-187605.

${ }^{33}$ See VAn Drooghenbroeck, supra note 3 , at 378.

${ }^{34}$ See VAn Drooghenbroeck, supra note 3, at 379.

${ }^{35}$ See VAN DroOghenBRoECK, supra note 3, at 379.

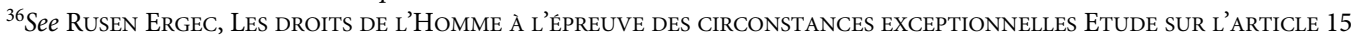
DE LA CONVENTION EUROPÉENnE DES DROITS DE L'HOMMe 34 (1987) (expressing the opinion that the intangibility of the substance of fundamental rights moreover constitutes a necessary assumption to justify the effet utile of the derogation scheme enshrined in Article 15 of the Convention in the whole system.).
} 
tion, ${ }^{37}$ the right of access to a judge, ${ }^{38}$ the right to marry, ${ }^{39}$ the right to silence, ${ }^{40}$ and the right to vote and to stand as a candidate in elections. ${ }^{41}$ The Court relied upon the purported logical and obvious prohibition of contracting parties to impair the substance of these rights to control national limitations made to them. Historically, this can simply be explained by the fact that declaring the inadmissibility of interferences because they impaired the very substance of these rights was easier for the European Judges than affirming, straight away and without any textual support, that the classical validity conditions of restrictions - for example, legality, legitimacy, and proportionality - were also applicable to implicit fundamental rights. ${ }^{42}$ Article 6 and Article 3, Protocol No. 1, indeed do not expressly grant the right of access to a judge nor the right to vote. They are, a fortiori, also silent about the admissibility conditions of their potential limitation. The respect of the essence was, from this point of view, the minimum minimorum easily acceptable by the contracting parties. Once European control on limitations of implicit rights gained, over time, some legitimacy, the clear-cut validity conditions-in particular the proportionality principleentered the scene in relation to these rights ${ }^{43}$ without, however, entailing the total eradication of the historical reference to the notion of the substance/core/essence by the Court.

The dedication of these conditions resulted in the shaping of a canonical formula, very close, in terms of structure, to what is now provided by Article 52 of the Charter of Fundamental Rights of the European Union. The recent judgment in the Naït-Liman ${ }^{44}$ case reproduces the formula elaborated in the Ashingdane judgment of 1985, regarding the validity conditions framing limitations made to the right of access to a tribunal:

The right of access to a court is not absolute, but may be subject to limitations; these are permitted by implication since the right of access by its very nature calls for regulation by the State, which enjoys a certain margin of appreciation in this regard ... That being stated, those limitations must not restrict or reduce a person's access in such a way or to such an extent that the very essence of the right is impaired ... In addition, such limitations will not be compatible with Article $6 \$ 1$ if they do not pursue a legitimate aim or if there is not a reasonable relationship of proportionality between the means employed and the aim sought to be achieved .... ${ }^{45}$

In parallel to this evolution, the reference made to the notion of "essence/substance/core" entered the sphere of rulings related to the admissibility of limitations made to the right to privacy, ${ }^{46}$ the freedom of religion, ${ }^{47}$ the freedom of association, ${ }^{48}$ or even-albeit more controversially - in relation to the principle of adversarial proceedings. ${ }^{49}$

Taking the above-mentioned canonical formula seriously implies that the justification test of fundamental rights' restrictions must follow a well-determined scheme. From a practical point of

\footnotetext{
${ }^{37}$ See The Belgian Linguistic Case, App. Nos. 1474/62, 1677/62, 1691/62, 1769/63, 1994/63, 2126/64, para. 5.

${ }^{38}$ See Golder v. United Kingdom, App. No. 4451/70, para. 38 (Feb. 21, 1975), http://hudoc.echr.coe.int/eng?i=001-57496.

${ }^{39}$ See Rees v. United Kingdom, App. No. 9532/81, para. 50 (Oct. 17, 1986), http://hudoc.echr.coe.int/eng?i=001-57564.

${ }^{40}$ See Serves v. France, App. No. 20225/92, para. 47 (Oct. 20, 1997), http://hudoc.echr.coe.int/eng?i=001-58103.

${ }^{41}$ See Mathieu-Mohin \& Clerfayt v. Belgium, App. No. 9267/81, para. 52 (Mar. 2, 1987), http://hudoc.echr.coe.int/eng? $\mathrm{i}=001-57536$.

${ }^{42}$ See VAn Drooghenbroeck, supra note 3, at 475.

${ }^{43}$ See VAn Drooghenbroeck, supra note 3, at 475.

${ }^{44}$ Naït-Liman, App. No. 51357/07, para. 112.

${ }^{45}$ Ashingdane v. United Kingdom, App. No. 8225/78, para. 57 (May 28, 1985), http://hudoc.echr.coe.int/eng?i=001-57425.

${ }^{46}$ See Phinikaridou v. Cyprus, App. No. 23890/02, para. 65 (Dec. 20, 2007), http://hudoc.echr.coe.int/eng?i=001-84106.

${ }^{47}$ See Sinan Isik v. Turkey, App. No. 21924/05, para. 42 (Feb. 2, 2010), http://hudoc.echr.coe.int/eng?i=001-97087.

${ }^{48}$ See Rhino v. Switzerland, App. No. 48848/07, para. 66 (Oct. 11, 2011), http://hudoc.echr.coe.int/eng?i=001-106893; Matelly v. France, App. No. 10609/10, para. 57 (Oct. 2, 2014), http://hudoc.echr.coe.int/eng?i=001-147063; Ognevenko v. Russia, App. No. 44873/09, para. 59 (Nov. 20, 2018), http://hudoc.echr.coe.int/eng?i=001-187732.

${ }^{49}$ See Regner, App. No. 35289/11, para. 148.
} 
view, the examination of the existence of a fundamental rights' core impairment must be madeas previously outlined-as a first step, before examining the goal and the proportionate character of the contested restriction. This is because not any aim in any circumstance could justify the impairment of a fundamental right's core.

ECtHR case law includes several orthodox applications of this methodology. For instance, in Baka v. Hungary, ${ }^{50}$ because the premature termination of the applicant's mandate as President of the Supreme Court was not open to any review by an ordinary tribunal or another body exercising judicial powers, the Court concluded that "the respondent State impaired the very essence of the applicant's right of access to a court." Neither the examination of the purpose nor a proportionality test followed in the reasoning of the Court: The finding of an infringement of the substance of the right of access to a tribunal, prior to any justificatory reasoning, was sufficient to conclude about the existence of a violation of Article 6. The same rationale can be found in other cases related to the right of access to a tribunal and to other freedoms, such as in the judgment in Matthews $v$. United Kingdom, which concerned the complete denial of the claimant's right to take part in the EU's elections, in breach of the "substance" of Article 3 Protocol No $1 .^{51}$

\section{II. ... To Practice: Critical Appraisal}

One must nevertheless observe that many other judgments do not follow the orthodox scheme of reasoning described above. This lack of consistency of the Strasbourg case law strengthens the practical difficulties surrounding the use of the analyzed concept. The first issue relates to the relationship between the concept of the essence of rights and the principle of proportionality ${ }^{52}$; the second issue relates to the content of the essence of rights. ${ }^{53}$

\section{The Essence of Rights vs. Proportionality: Absolutist and Relativist Approaches}

The "canonical formula" examined above implies a radical distinguishing between two steps of the reasoning: On the one hand, the assessment of the respect of the essence of the impaired right and, on the other hand, the examination of the respect of the principle of proportionality. Nevertheless, the analysis of the ECHR's case law on this point is very puzzling because of its methodological fuzziness. It indeed invites envisaging other types of articulation between the concepts of the essence of rights and proportionality entailing either a partial recovery or, even, a complete assimilation of both concepts.

The judgment of the Court in Rhino v. Switzerland is symptomatic of a methodological weakness leading to this debate. The Court held that, regarding the dissolution of an association whose members were occupying buildings without the authorization of the owners, "the Government has not sufficiently shown that the dissolution, which undermined the very substance of the applicants' freedom of association, was the only option for the fulfilment of the aims pursued by the authorities." 54 The Court then continued its reasoning with a proportionality test, by stressing that "other measures could have been taken that would have less seriously interfered with the right guaranteed by Article 11," and that, "consequently, the interference cannot be regarded as proportionate to the aims pursued." ${ }^{2}$ This line of argumentation implies that the impairment of the freedom of association's core could possibly have been considered as justified in other circumstances. The idea of an "unjustifiable" per se seems—at least implicitly- to be heavily undermined. A similar observation can be made in Prince Hans-Adam II concerning the right of access to a court where

\footnotetext{
${ }^{50}$ Baka v. Hungary, App. No. 20261/12, para. 120 (June 23, 2016), http://hudoc.echr.coe.int/eng?i=001-163113.

${ }^{51}$ Matthews v. United Kingdom, App. No. 24833/94, para. 63 (Feb. 18, 1999), http://hudoc.echr.coe.int/eng?i=001-58910.

${ }^{52}$ See infra Part B(II)(1).

${ }^{53}$ See infra Part $\mathrm{B}(\mathrm{II})(2)$.

${ }^{54}$ Rhino, App. No. 48848/07, para. 66 (emphasis added).

${ }^{55}$ Id.
} 
the Court considered that the very essence of this right was not impaired because the principle of proportionality was respected. According to the Court:

[T] he German court decisions declaring the applicant's ownership action inadmissible cannot be regarded as disproportionate to the legitimate aim pursued and they did not, therefore, impair the very essence of the applicant's "right of access to a court" within the meaning of the Court's case law .... It follows that there has been no breach of the applicant's right to a court, as guaranteed by Article $6 \$ 1$ of the Convention. ${ }^{56}$

As a matter of fact, Judge Costa very clearly underlined, in his concurring opinion to this case, the methodological deficiency of the reasoning by referring to the Ashingdane canonical formula. Notably, he stressed the lack of methodology evidenced by the reasoning examining the proportionality of the measure hand in hand with the assessment of the respect of the essence of the right impaired. As he observed, this approach is "both unorthodox and illogical," because the question of proportionality should only arise "as a subsidiary issue, in the event that the very essence of the right to a court has not been affected." 57

These are two examples amongst many. The proliferation of these cases questioned the genuine embodiment of the fundamental freedoms' "substance/core/essence" as an authentic unsjustifiable per se. They resulted in different readings of this concept. ${ }^{58}$ To some-adopting a "relativist" perspective - a limitation to the essence/core/substance of a fundamental right simply amounts to a disproportionate impairment of this right in the specific circumstances of the case. ${ }^{59}$ In other words, the extent of a right's core is the "product of its environment" 60 and can be identified only after a balancing test-relativist assimilation. For this reading, there are no genuinely unjustifiable actions, but only actions which can be considered as being unjustified. On the contrary, the "absolutist" reading — suggested by the canonical rulings previously highlighted, and in compliance with them - considers that cores of fundamental rights remain outside of the scope of the principle of proportionality, as they constitute a distinctive element which cannot be limited in any circumstances, regardless of the aim pursued and the means used. ${ }^{61}$ Cores thus amount to "guaranteed legal position[s] that no possible or conceivable legal justification can ever limit." 62

To further complicate things, we must also notice that the absolutist doctrine has two variantsthe "pragmatic" and the "radical" absolutism. ${ }^{63}$ The first- the pragmatic absolutism-acknowledges a link between the proportionality principle and the concept of the essence of fundamental rights. It considers whether any disproportionate limitation to a fundamental right does not constitute an offense to the limited right's core per se. Here is the major difference with the relativist theory-any offense to a right's core will amount to a disproportionate restriction. ${ }^{64}$ One example of this reasoning can be found in the wording of the conclusion of the Matelly $v$. France judgment, concerning the compatibility of Article 11 with a blanket ban on the right of military personnel to form and join a trade union. According to the Court:

While the freedom of association of military personnel may be subject to legitimate restrictions, the outright prohibition on forming or joining a trade union impairs the very essence

\footnotetext{
${ }^{56}$ Prince Hans-Adam II of Liechtenstein v. Germany, App. No. 42527/98, para. 69 (July 12, 2001) (emphasis added), http:// hudoc.echr.coe.int/eng?i=001-59591.

${ }^{57} I d$. (Costa, J., concurring).

${ }^{58}$ Rivers, supra note 3, at 184; van der Schyff, supra note 13, at 134; Brkan, supra note 3, at 22.

${ }^{59}$ VAn Drooghenbroeck, supra note 3, at 361.

${ }^{60}$ van der Schyff, supra note 13 , at 134.

${ }^{61}$ VAN DrooghenBRoECK, supra note 3, at 362.

${ }^{62}$ van der Schyff, supra note 13 , at 134.

${ }^{63}$ VAN DrooghenBroeck, supra note 3 , at 362.

${ }^{64}$ VAN Drooghenbroeck, supra note 3 , at 362.
} 
of that freedom. Consequently, the interference cannot be considered as being proportionate and was therefore not "necessary in a democratic society" within the meaning of Article $11 \S$ 2 of the Convention. ${ }^{65}$

"Consequently, the interference cannot be considered as being proportionate ...." What infringes the substance of a fundamental right is necessarily disproportionate-this is precisely the "cutting edge" of the pragmatic absolutism. In this scheme, the explicit reference to the substance and the case-by-case verification of its integrity lose a great part of their practical usefulness. The principle of proportionality logically suffices in itself to ensure the desired integrity-known as pragmatic inclusion.

In contrast, the radical absolutist doctrine assumes the usefulness of two separate and independent intellectual steps consisting of: First, the verification of the respect of the essence of the fundamental right by the limitation before; and second, the assessment of its proportional character-known as radical distinction. ${ }^{66}$

\section{The Institutional or Subjective Approaches}

Besides these questions concerning the essence's relationship with the principle of proportionalitywhether through relativist assimilation, pragmatic inclusion, or radical distinction - the identification of the essence of fundamental rights remains problematic. As recalled by the Judges Raimondi, Sicilianos, Spanon, Ravariani, and Pastor Vilanova in the recent Regner case, ${ }^{67}$ it is not satisfactory to conclude, in given cases, that the "essence/substance/core" of a right is not impugned, without in parallel specifying what this "essence/substance/core" consists of. Yet, many difficulties exist in this field, which are not confined to the case law of the ECtHR. Admittedly, he unalienable core elements can easily be identified in relation to specific rights such as nonderogable rights, whose content is equivalent to its substance or the freedom of thought and the freedom of religion, as including the internal aspect of these freedoms, namely the thought itself and the right to have convictions ${ }^{68}$. Nevertheless, the concept usually remains elusive in the judgments dedicated to other rights, as well as in the relevant legal literature. ${ }^{69}$ Affirming that the "hard core" of a right is the part of it that is the most closely linked to the principle of human dignity is doubtless accurate, ${ }^{70}$ but does not in itself facilitate the elucidation of the notion, because the concept of "human dignity" also remains relatively ambiguous.

With respect to this question, the relevant German literature ${ }^{71}$ classically opposes the "institutional" and "subjective" approaches to cores. One branch of the scholarship, adopting an "institutional" perspective, considers that a fundamental freedom's core is infringed "only when such a right loses its meaning for all or nearly all individuals and not just a particular individual or at least a few individuals."72 At the opposite end of the spectrum, the subjective approach centers itself on the individual and holds that there might be an infringement of the core of a right by a limitation leaving the right as an institution unimpaired, but voiding it of its substance for one individual. ${ }^{73}$

The dissenting opinion of Judge Wojtyczek in Naït-Liman v. Switzerland of March 10, 2018 expressly "imported," for the first time to our knowledge, this doctrinal debate into the discourse

\footnotetext{
${ }^{65}$ Matelly, App. No. $10609 / 10$ at paras. $75-76$.

${ }^{66}$ VAN DROOGHENBROECK, supra note 3, at 363.

${ }^{67}$ Regner, App. No. 35289/11 (Raimondi, Sicilianos, Spano, Ravarani \& Paster Vilanova, JJ., partly dissenting).

${ }^{68}$ VAn Drooghenbroeck, supra note 3, at 433.

${ }^{69}$ See e.g., Rivers, supra note 3, at 186; Rouzière-Beaulieu, supra note 5, at 309.

${ }^{70}$ Regner, App. No. 35289/11, para. 59 (Serghides, J., partly dissenting); Brkan, supra note 3, at 13.

${ }^{71}$ See Krüger Herbert, Der Wesensgehalt der Grundrechte, EUGRZ 323 (1985).

${ }^{72}$ van der Schyff, supra note 13, at 133.

${ }^{73}$ VAN DROOGHENBROECK, supra note 3, at 372.
} 
of the ECtHR. In his view, this question strengthens the inconsistency of the ECHR case law. He noted, in that regard, that:

The concept of the substance of a fundamental right . . . is the subject of conflicting legal theory. In particular, legal scholarship discusses whether this concept ought to be attached to an individual legal position or to the objective guarantee of a legal institution and whether it should be understood as an absolute or relative guarantee. ${ }^{74}$

Discussing the canonical formula relied upon by the Court in the case at hand in relation to the right of access to a tribunal, the Polish judge continued his reasoning by stressing that "the requirement to comply with the concept of the substance of a right, formulated without further explanation and without being effectively applied, gives no clear indication to the High Contracting Parties as to the content of their obligations and does not promote legal certainty." ${ }^{75}$

\section{The Essence of Fundamental Rights: A Vehicle for the Expansion of the ECHR's Sphere of Protection}

In addition to the classical function consisting of being a validity condition framing limitations to fundamental rights, the concept of essence of rights also occupies, in the case law of the ECHR, another function which is more of an interpretative nature and is not specifically related to the potentially justifiable or unjustifiable character of the disputed limitations. Indeed, in several cases, the idea of the essence/core/substance of fundamental rights has been cited "upstream," in order to determine the scope of the ECHR's protection, and not "downstream", in examining the validity of a restriction upon a fundamental right.

In line with the well-known principle that the "Convention is intended to guarantee not theoretical or illusory rights, but rights that are practical and effective," $"$ the ECtHR has developed different interpretative techniques to safeguard, to the greatest extent possible, the effectiveness of the Convention's provisions. ${ }^{77}$ Yet, for the ECtHR, one of those techniques consisted of relying precisely upon the purported existence of a "hard core of fundamental rights," or of related concepts, to justify the expansion of the ECHR's sphere of protection (Shutzbereich) for the purposes of guaranteeing the effet utile of some of its provisions.

In this way, the use of the concept of the essence/substance/core has enabled the Court to expand the material ${ }^{78}$ as well as the territorial/personal ${ }^{79}$ scope of the Convention. Although similar rationales have been invoked by a number of other jurisdictions, ${ }^{80}$ the case law of the ECtHR is, nevertheless, not immune from criticism. ${ }^{81}$

\section{The Essence of Fundamental Rights: A Vehicle for the Expansion of the ECHR's Material Sphere of Protection}

In respect of the ECHR's material sphere of protection, the ECtHR has on several occasions used the concept of the "very substance" of fundamental rights in order to circumvent the eventuality where a limitation of a right not expressly provided for by the Convention nonetheless led to a

\footnotetext{
${ }^{74}$ Naït-Liman, App. No. 51357/07 (Wojtyczek, J., partly dissenting).

${ }^{75} \mathrm{Id}$.

${ }^{76}$ Airey v. Ireland, App. No. 6289/73, para. 24 (Oct. 9, 1979).

${ }^{77}$ Johan Callewaert, La Convention des droits de l'homme entre effectivité et prévisibilité, in LES DROITS DE L'HOMME AU SEUIL DU troisième millénaire: Mélanges en hommage à Pierre lambert 93 (2000).

${ }^{78}$ See infra Part C(I).

${ }^{79}$ See infra Part C(II).

${ }^{80}$ See infra Part C(III).

${ }^{81}$ See infra Part C(IV).
} 
restriction — which could possibly be justified — of a right that is conventionally protected. ${ }^{82}$ Two rights have been subject to this interpretative technique and have thus had their material scope expanded for the purposes of protecting what the Court considered as belonging to their essence.

The first freedom whose core the Court relied upon is the freedom of association. Enshrined in Article 11 ECHR, the freedom of association is only perceived by the text of the Convention in its "positive aspect," as covering everyone's right to join an association. ${ }^{83}$ Indeed, contrary to the Universal Declaration of Human Rights, which also expressly states that "[n]o one may be compelled to belong to an association," ${ }^{44}$ the text of the ECHR does not, expressis verbis, enshrine freedom of association in its negative aspect. Nevertheless, the ECHR held in its judgment in Young, James and Webster that: "To construe Article 11 as permitting every kind of compulsion in the field of trade union membership would strike at the very substance of the freedom it is designed to guarantee." 85

The case concerned a "closed-shop" agreement between British Rail and several trade unions providing that thenceforth membership of one of those unions was a condition of employment. Failing to satisfy this condition, the applicants were dismissed and alleged that the dismissal infringed Article 11 ECHR. Although freedom of association was not expressly enshrined in the text of the Convention, the ECtHR, relying upon the very substance of the freedom of association, held that the negative aspect of a person's freedom of association had to be considered as falling into the ambit of Article 11 ECHR. This statement did not, however, result in any restriction to the negative facet of the freedom of association being per se unlawful. As exemplified by the ruling in this judgment and by the subsequent case law, the determination of the validity of such interference in the negative freedom of association remains based on a broader assessment of the measure, which includes the examination of the pursued objective as well as the proportionality of the means employed. ${ }^{86}$ A limitation to this right in its negative sense could thus possibly be considered as justified by the Court. As a matter of fact, in Young, James and Webster, the ECtHR underlined-after having considered that it fell into the ambit of Article 11 ECHR - that the limitation in question could not be considered as admissible because it "went further than was required to achieve a proper balance between the conflicting interests of those involved." ${ }^{87}$ In this judgment, the function assigned to the notion of the substance of freedom of association does not directly equate with the idea of an unjustifiable per se limitation classically attached to this concept. ${ }^{88}$

One year later, the Court had recourse to the same interpretative technique in respect of the protection of property. ${ }^{89}$ In Sporrong and Lönnroth, ${ }^{90}$ the Court had to examine the compatibility of long-term expropriation permits and prohibitions on construction with Article 1 of Protocol

\footnotetext{
${ }^{82}$ See VAn Drooghenbroeck, supra note 3, at 428.

${ }^{83}$ See Isabelle Van Hiel, The Right to Form and Join Trade Unions Protected by Article 11 ECHR, in THE EUROPEAN Convention on Human Rights and the Employment Relation 287 (Filip Dorssemont, Klaus Lörcher \& Isabelle Schömann, eds., 2013).

${ }^{84}$ The Universal Declaration of Human Rights art. 20(2), Dec. 10, 1948.

${ }^{85}$ Young, James \& Webster v. United Kingdom, App. Nos. 7601/76, 7806/77, para. 52 (Aug. 13, 1981) (emphasis added), http://hudoc.echr.coe.int/eng?i=001-57608.

${ }^{86}$ See Sibson v. United Kingdom, App. No. 14327/88, para. 29 (April 20, 1993), http://hudoc.echr.coe.int/eng?i=001-57843; Chassagnou v. France, App. Nos. 25088/94, 28331/95, 28443/95 (Apr. 29, 1999), http://hudoc.echr.coe.int/eng?i=001-58288; Sørensen \& Rasmussen v. Denmark, App. Nos. 52562/99, 52620/99, para. 56 (Jan. 11, 2006), http://hudoc.echr.coe.int/eng? $\mathrm{i}=001-72015$; VAN DroOGHENBROECK, supra note 3, at 432.

${ }^{87}$ Young, James \& Webster, App. Nos. 7601/76, 7806/77 at para. 65.

${ }^{88}$ See supra Part A.; VAN DroOGHENBROECK, supra note 3, at 433.

${ }^{89}$ See Yves Haeck, The Genesis of the Property Clause Under Article 1 of the First Protocol to the European Convention on Human Rights, in PropriÉtÉ et droits de L'homme-Property and Human Rights 163 (Hugo Vandenberghe ed., 2006).

${ }^{90}$ Sporrong \& Lönnroth v. Sweden, App. Nos. 7151/75, 7152/75 (Sept. 23, 1982), http://hudoc.echr.coe.int/eng?i=00157580. For a recent overview of this case law, see also the dissenting opinion of Judge Pinto De Albuquerque in Albert v. Hungary, App. No. 5294/14 (Jan. 29, 2019), http://hudoc.echr.coe.int/eng?i=001-189631.
} 
No 1. Although the owners' abilities to use and dispose of their property were left intact because the expropriation permits were not used by the authorities, they affected, according to the Court, "the very substance of ownership in that they recognized before the event that any expropriation would be lawful and authorized the City of Stockholm to expropriate whenever it found it expedient to do so." ${ }^{11}$ In that way, the reliance upon the "very substance" of the right enabled the ECtHR to apply Article 1 of Protocol No. 1 even though the claimants were not as such deprived of their property. ${ }^{92}$ Just as in Young, James and Webster, the Court then examined whether the limitation was justified or not by the use of the classic balance of interests method. Accordingly, the fact that these permits affected the "very substance of ownership" did not prevent the existence of an admissible justification; it justified solely the application of the scope of Article 1 of Protocol No. 1 beyond the strict reading of its text.

\section{The Essence of Fundamental Rights: A Vehicle for the Expansion of the ECHR's Personal/ Territorial Sphere of Protection}

The use of the idea of the essence/core/substance as a vehicle for expanding the ECHR's sphere of protection for the purposes of effectiveness can also be observed in relation to its territorial/personal scope of application. Admitting that the contracting parties cannot be required to control the full and effective enforcement of all the rights and freedoms set out in the Convention by third states when cooperating with them, ${ }^{93}$ the ECtHR nevertheless held that the contracting parties' liability could be engaged when they indirectly enable the breach of important components of the fundamental freedoms, or when they give effectiveness to a particularly serious infringement committed previously by third parties. The Court indeed considered in the Soering case that, although "the Convention does not govern the actions of States not Parties to it, nor does it purport to be a means of requiring the Contracting States to impose Convention standards on other States," 94 the absolute character and the fundamental importance of the prohibition of torture and of inhuman or degrading treatment or punishment found in Article 3 of $\mathrm{ECHR}^{95}$ has to be construed as precluding the surrender of "a fugitive to another State where there were substantial grounds for believing that he would be in danger of being subjected to torture." 96

The Court specified in F. v. UK that this reasoning was "based on the fundamental importance of these provisions whose guarantees it is imperative to render effective in practice," 97 and that it does not "automatically apply under the other provisions of the Convention." ${ }^{8}$ In the case at hand, the plaintiff was claiming that his expulsion to Iran, where homosexuality is prohibited by law, would violate his rights under Article 8 of the ECHR because of his sexual orientation. Considering that it had not been established "that the applicant's moral integrity would be substantially affected to a degree falling within the scope of Article 8 of the Convention," the Court declared the application inadmissible.

Regarding Article $6 \mathrm{ECHR}$, the contracting states are, according to the Court's judgment in Drozd and Janousek, "obliged to refuse their cooperation [with third states] if it emerges that the conviction is the result of a flagrant denial of justice."

\footnotetext{
${ }^{91}$ Sporrong \& Lönnroth v. Sweden, para. 60 (emphasis added).

${ }^{92}$ VAn Drooghenbroeck, supra note 3, at 439.

${ }^{93}$ Soering v. United Kingdom, App. No. 14038/88, para. 86 (July 7, 1989), http://hudoc.echr.coe.int/eng?i=001-57619. See also, Öcalan v. Turkey, App. No. 46221/99, paras. 199-213 (Mar. 12, 2003), http://hudoc.echr.coe.int/eng?i=00169022; F. v. United Kingdom, App. No. 17341/03 (June 22, 2004).

${ }^{94}$ Soering, App. No. $14038 / 88$ at para. 86.

${ }^{95} \mathrm{Id}$. at para. 88 .

${ }^{96} \mathrm{Id}$. at para. 88 .

${ }^{97}$ F. v. United Kingdom, App. No. 17341/03 (decision on admissibility).

${ }^{98} I d$.

${ }^{99}$ Drozd \& Janousek v. France \& Spain, App. No. 12747/87, para. 110 (June 26, 1992), http://hudoc.echr.coe.int/eng?i=00157774.
} 
of justice" should logically entail that not any infringement to the right to a fair trial committed by a third state prevents extradition, but that only the denial of the core of Article 6 would induce the indirect liability of the extraditing contracting state. Indeed, although the contracting parties shoulder a limited territorial/personal liability, "the Court does not exclude that an issue might exceptionally be raised under Article 6 by an extradition decision in circumstances where the fugitive has suffered or risks suffering a flagrant denial of a fair trial in the requesting country." 100 This idea of a "flagrant denial of a fair trial" has been explicitly translated, in the Othman (Abu Qatada) case, ${ }^{101}$ into the discourse of the substance/core/essence:

A flagrant denial of justice goes beyond mere irregularities or lack of safeguards in the trial procedures such as might result in a breach of Article 6 if occurring within the Contracting State itself. What is required is a breach of the principles of fair trial guaranteed by Article 6 which is so fundamental as to amount to a nullification, or destruction of the very essence, of the right guaranteed by that Article. ${ }^{102}$

\section{The Essence of Fundamental Rights as a Vehicle of Expansion in Other Legal Systems}

The use of the idea of the core/substance/essence of fundamental rights thus enabled the Court to legitimize the extension of the ECHR's material and territorial/personal scope of protection. One can observe that this practice, as well as its justification, are not isolated. In the same vein, ${ }^{103}$ the European Committee of Social Rights considered, for instance, that people in an illegal situation could not be deprived, under the Revised Social Charter, of certain rights belonging to "the core of positive European human rights law", ${ }^{104}$ including the right to life and dignity. Despite that, the appendix to the European Social Charter limits its personal scope of application to foreigners "in so far as they are nationals of other Parties lawfully resident or working regularly within the territory of the Party concerned." 105 On the basis of the core of rights rhetoric, the European Social Committee condemned, inter alia, the denial of the right to medical assistance to irregular foreign nationals ${ }^{106}$ and the brutal expulsion of Roma from their camps. ${ }^{107}$

The use of the idea of the core/essence/substance of rights as a tool for expanding the scope of international protection can furthermore be found in the case law of the European Court of Justice (ECJ). The ECJ indeed held, in the Zambrano judgment that, because "Article 20 TFEU precludes national measures which have the effect of depriving citizens of the Union of the genuine enjoyment of the substance of the rights conferred by virtue of their status as citizens of the Union," 108 the refusal to grant a right of residence and a work-permit to a third country national with

\footnotetext{
${ }^{100}$ Soering, App. No. 14038/88 at para. 113.

${ }^{101}$ See also, Ahorugeze v. Sweden, App. No. 37075/09, para. 115 (June 4, 2012), http://hudoc.echr.coe.int/eng?i=001107183; Maumousseau \& Washington v. France, App. No. 39388/05, para. 98 (Dec. 6, 2007), http://hudoc.echr.coe.int/ eng? $\mathrm{i}=001-83823$ (referring to the "essential guarantees of Article 6 of the Convention").

${ }^{102}$ Othman (Abu Qatada) v. United Kingdom, App. No. 8139/09, para. 260 (May 9, 2012), http://hudoc.echr.coe.int/eng? $\mathrm{i}=001-108629$. See also Al Nashiri v. Romania, App. No. 33234/12, para. 717 (May 31, 2018) (emphasis added), http://hudoc. echr.coe.int/eng? $\mathrm{i}=001-183685$.

${ }^{103}$ See Nicolas Bernard, Le Droit au Logement des Migrants, 40 Administration Publique Trimestriel 20, 39 (2017); Europees Sociaal Handvest, Sociale Rechten en Grondrechten op de Werkvloer 149 (Sébastien Van Drooghenbroeck, Filip Dorssemont \& Guido Van Limberghen, eds., 2016).

${ }^{104}$ The International Federation of Human Rights Leagues (FIDH) v. France, Complaint No. 14/2003, European Committee of Social Rights (Nov. 3, 2004) (emphasis added).

${ }^{105}$ Council of Europe, European Social Charter (Revised), app., para. 1 (1996).

${ }^{106}$ FIDH v. France, Complaint No. 14/2003, para. 32.

${ }^{107}$ Médecins du Monde-International v. France, Complaint No. 67/2011, European Committee of Social Rights (Sept. 11, 2012).

${ }^{108}$ Case C-34/09, Zambrano v. Office national de l'emploi (ONEm), paras. 32-33 (Mar. 8, 2011) (emphasis added) https:// curia.europa.eu.
} 
dependent minor children in the Member State where those children are nationals and reside is contrary to EU law. For the first time in this judgment, ${ }^{109}$ the ECJ accepted the reliance upon Articles 20 and 21 of the TFEU by sedentary EU citizens-in Zambrano: The children-precisely for the purposes of protecting the substance of their EU citizenship rights.

\section{The Essence of Fundamental Rights as a Vehicle for the Expansion of the ECHR's Sphere of Protection: Critical Assessment}

So far, so clear? Not exactly. Indeed, it must be observed that the ECtHR case law discussed in the preceding paragraphs is rife with ambiguities and inconsistencies, which encompass, on the one hand, the definition of what belongs to the essence/substance/core and, on the other hand, the reasoning of the Court itself. Indeed, it must be observed that the case law of the Court again does not explicitly identify what belongs to the core of fundamental rights. It also does not offer any satisfactory justification about the transposition of the concept of essence-classically attached to the limitation scheme-to the determination of the Convention's sphere of protection. This transposition is, therefore, in itself confusing.

In addition, the Court's reasoning regarding the link between the territorial scope of the Convention and the potential breach of a fundamental right's core is not immune from any contradiction. The notion of a "flagrant denial of justice," whose perpetration in a third state could possibly expose a contracting party's liability, has indeed not been fully consolidated by the Court: Pragmatic reasoning was gradually built upon by slow accretion, on a case by case basis. ${ }^{110}$ The judgment in Pellegrini ${ }^{111}$ is illustrative in that respect: In that case, a judgement issued by a third party - the Vatican — was also recognized by a contracting party-Italy. Contrary to the judgment in Drozd and Janousek, the fact that the alleged infringement was not made by a contracting state did not lead the Court to limit the liability to the sole infringement of Article 6, constituting a "flagrant denial of justice." Quite the contrary: The fact that the judgment was rendered by a third party justified, according to this judgment, full control of the respect of Article 6 by the executing judge. This curiosum, which did not escape Judge Costa's notice, ${ }^{112}$ has not yet been clarified by the Court. Moreover, in Maumousseau \& Washington v. France, ${ }^{113}$ the Court simultaneously applied the Soering and Pellegrin tests, as if they were complementary, while they actually seem difficult to reconcile.

\section{The Essence of Fundamental Rights: A Technique for Prioritizing Values}

Besides being a validity-condition of human rights' limitations and a vehicle for expanding the ECHR's sphere of protection for the purposes of its effectiveness, the idea of the essence of fundamental rights also seems to constitute a tool for the ECtHR when it has to prioritize different interests at stake in a particular case. In other words, it also fulfils the role of a criterion making it possible to gauge, where required, the different aspects constituting the rights protected by the Convention. Indeed, the notion of core/substance/essence or other related concepts have been invoked by the ECtHR on several occasions when it had to establish priorities among a series of values at stake. Again, this function is not directly equated with the question of the potentially

\footnotetext{
${ }^{109}$ Luc Leboeuf, La citoyenneté européenne appliquée aux situations purement internes: portée et enjeux des arreêts Zambrano et Mc Carthy, JURsiprudenCE LIĖGE MONs Bruxelles 1128 (2011).

${ }^{110}$ See European Court of Human Rights, GUIDE SUR L'ARTICle 6 DE LA CONVENTION EUROPÉENNE DES DROITS DE L'HOMME: DROIT À UN PROCÈS ÉQUITABLE, para. 351 (Dec. 31, 2018) https://www.echr.coe.int/Documents/Guide_Art_6_criminal_FRA.pdf; Dean Spielmann, L'étendue du contrôle du respect des droits fondamentaux à l'aune de l'expérience judiciaire comparée, REVUE TRIMESTRIELLE DES DROITS DE L'HOMME 897-952 (2017).

${ }^{111}$ Pellegrini v. Italy, App. No. 30882/96, para. 40 (July 20, 2001), http://hudoc.echr.coe.int/eng?i=001-59604.

${ }^{112}$ Jean-Paul Costa, Observations sur l'arrêt Pellegrini c. Italie, RevUe Trimestrielle DES DROITS DE L'HOMME 474 (2002).

${ }^{113}$ Maumousseau, App. No. 39388/05 at paras. 96, 98.
} 
inalienable aspects of fundamental rights which are totally — at least in theory-excluded from any possible restriction.

The determination of what belongs to the rights' essential or peripheral components here plays the role of a criterion used-among others-by the Court in its assessment. This criterion has been notably put forward, in a more or less explicit way, for resolving conflicts between fundamental rights, ${ }^{114}$ for determining the procedural safeguards applicable under Article 6 ECHR, ${ }^{115}$ for deciding upon obligations binding the Member States of the European Union under the ECHR, ${ }^{116}$ and for ascertaining the margin of appreciation of national authorities in various cases. ${ }^{117}$ One must admit that, in these fields, the case law is not immune to criticism either. ${ }^{118}$

\section{The Essence of Fundamental Rights as a Criterion for Resolving Conflicts Between Fundamental Rights}

The notion of the essence of fundamental rights is one of the tools that the ECtHR has on occasion used to resolve conflicts between fundamental rights. As asserted by Smet, determining the core of fundamental rights enables the Court, in presence of a conflicts of rights, "to assess whether damage is done to a central or to a peripheral aspect of the Convention rights in conflicts," 119 and thereby to find in favor of the right which suffers from "an interference with an aspect that lies closer to its core." ${ }^{20}$ The use of this technique can be illustrated, among others, by the ruling of the ECtHR in Biriuk v. Lithuania. ${ }^{121}$ The case concerned the publication of an individual's HIV status in a newspaper. Confronted with a conflict between the newspaper's freedom of expression and the individual's right to privacy, the Court found in favor of Article 8 of the Convention after having observed that "the protection of personal data, not least medical data, is of fundamental importance to a person's enjoyment of his or her right to respect for private and family life as guaranteed by Article 8 of the Convention," 122 and, moreover, that there was no public interest justifying the publication of this kind of information. ${ }^{123}$ Smet finds in this outcome an application of what he calls the "core-periphery criterion": The right to privacy was compromised with regard to one of its more central aspects, while the freedom of expression was only limited in one of its peripheral aspects. ${ }^{124}$

\section{The Essence of Fundamental Rights as a Criterion for Determining the Applicable Procedural Safeguards Provided by Article 6}

The concept of essence of fundamental rights has also been more or less implicitly relied upon in order to determine - in the framework of a balancing of interests - the most important guarantees of the right to a fair trial that have to be complied with in any case, irrespective of the particular type of case or procedure concerned.

In the judgment in Jussila, the Court underlined that, because " $[\mathrm{t}]$ here are clearly 'criminal charges' of differing weight ... criminal-head guarantees [under Article 6 of ECHR] will not necessarily apply with their full stringency" ${ }^{\prime 25}$ to all cases such as those concerning tax surcharges,

\footnotetext{
${ }^{114}$ See infra Part D(I).

${ }^{115}$ See infra Part D(II).

${ }^{116}$ See infra Part D(III).

${ }^{117}$ See infra Part D(IV)

${ }^{118}$ See infra Part $\mathrm{D}(\mathrm{V})$.

${ }^{119}$ Stijn Smet, Resolving Conflicts Between Human Rights: The Judge's Dilemma (2017) 160.

${ }^{120} I d ., 160$.

${ }^{121}$ Biriuk v. Lithuania, App. No. 23373/03 (Nov. 25, 2008), http://hudoc.echr.coe.int/eng?i=001-89827.

${ }^{122} I d$. at para. 39.

${ }^{123} \mathrm{Id}$. at para. 42 .

${ }^{124}$ See Stijn Smet, Conflicts between Human Rights and the ECtHR. Towards a Structured Balancing Test, in WHEN HUMAN Rights Clash at the European Court of Human Rights 47 (Eva Brems \& Stijn Smet, eds., 2017).

${ }^{125}$ Jussila v. Finland, App. No. 73053/01, para. 43 (Nov. 23, 2006), http://hudoc.echr.coe.int/eng?i=001-78135.
} 
which "differ from the hard core of criminal law."126 Thus, depending on whether the charges belong to the hard core or to the periphery of criminal law, the guarantees that must be complied with may differ. Within the periphery of criminal law, only certain safeguards of Article 6-the core guarantees, or the essence of the right to a fair trial-must necessarily be complied with. Conversely, within the "hard core of criminal law," the "full option" right to a fair trial is promised: In addition to respecting the essential content of Article 6 ECHR, the trial must also observe the peripheral guarantees provided by the Convention. ${ }^{127}$

In the same vein, the Court implicitly relied upon the idea of the essence of the right to a fair trial in the Micallef judgment in order to determine the guarantees of Article 6 applicable to interim measures. After considering that "whenever an interim measure can be considered effectively to determine the civil right or obligation at stake, notwithstanding the length of time it is in force, Article 6 will be applicable," 128 the Court underlined, that, nonetheless,

in exceptional cases - where, for example, the effectiveness of the measure sought depends upon a rapid decision-making process - it may not be possible immediately to comply with all of the requirements of Article 6. Thus, in such specific cases, while the independence and impartiality of the tribunal or the judge concerned is an indispensable and inalienable safeguard in such proceedings, other procedural safeguards may apply only to the extent compatible with the nature and purpose of the interim proceedings at issue. ${ }^{129}$

Once again, a distinction is made between core and peripheral prerogatives provided by Article 6.

\section{The Essence of Fundamental Rights as a Criterion for Deciding Upon the Obligations Binding the Member States of the European Union Under the ECHR}

The criterion of the core of fundamental rights can also be, at least implicitly, perceived in the case law of the ECtHR in relation to the specific situation of the contracting parties that are additionally Members of the European Union.

Firstly, the occurrence of this criterion is perceptible in judgments implementing the Bosphorus doctrine. ${ }^{130}$ This case law, ${ }^{131}$ which relies upon the "equivalent protection" of fundamental rights in the EU legal order as in the ECHR, concedes to national acts implementing EU obligations, leaving Member States with no margin of appreciation, a presumption of compliance with the Convention's requirements. Aiming at accommodating the ECHR's obligations and the duties resulting from the accession to the European Union, the Bosphorus principle, in other words, assumes that "a State has not departed from the requirements of the Convention when it does no more than implement legal obligations flowing from its membership of the organisation."132

\footnotetext{
${ }^{126} I d$.

${ }^{127}$ The distinction between the "hard core" and the "periphery" of criminal law has also been relied upon by the ECtHR in its application of the ne bis in idem principle. See A \& B v. Norway, App. Nos. 24130/11, 29758/11, para. 133 (Nov. 15, 2016).

${ }^{128}$ Micallef v. Malta, App. No. 17056/06, para. 85 (Oct. 15, 2009), http://hudoc.echr.coe.int/eng?i=001-95031. See also Frédéric Krenc, L'assujettissement du référé aux garanties du procés équitable, obs. sous Cour eur. dr. h., gde ch., arrêt Micallef c. Malte du 15 octobre 2009, in RevUe trimestrielle DES DROITS DE L'HOMME, 295-315 (2011); Jean-François Van Drooghenbroeck \& Sébastien Van Drooghenbroeck, Référé et procès équitable (note sous Cass., 14 janvier 2005), Revue Critique de Jurisprudence Belge, 507-55 (2006).

${ }^{129}$ Micallef, App. No. 17056/06 at para. 86. See also A.K. v. Liechtenstein, App. No. 38191/12, para. 55 (July 9, 2015) (emphasis added), http://hudoc.echr.coe.int/eng?i=001-155824.

${ }^{130}$ Bosphorus v. Ireland, App. No. 45036/98 (June 30, 2005), http://hudoc.echr.coe.int/eng?i=001-69564.

${ }^{131}$ See, on that case law, Steve Peers, Bosphorus-European Court of Human Rights, 2 Eur. Const. L. REv. 443 (2006); Cédric Ryngaert, The European Court of Human Rights' Approach to the Responsibility of Member States in Connection with Acts of International Organizations, 60 INT'L \& COMP. L.Q. 997 (2011).

${ }^{132}$ Bosphorus, App. No. 45036/98 at para. 155.
} 
This presumption is nevertheless neither automatic ${ }^{133}$ and eternal, nor absolute: It can be rebutted in concreto. The ECtHR indeed stressed that, "any such presumption can be rebutted if, in the circumstances of a particular case, it is considered that the protection of Convention rights was manifestly deficient." ${ }^{\prime 34}$. Not all infringements of human rights in the EU legal order would thus entail the rebuttal of the Bosphorus presumption. It seems, in our view, that only a manifest infringement, which could consist of a denial of the core aspects of the fundamental freedoms would justify such rebuttal. This observation can be supported by the analysis of the roots of the Bosphorus judgement. As underlined by De Schutter, ${ }^{135}$ "the approach of the Court clearly was inspired by the attitude of the German Federal Constitutional Court (Bundesver-fassungsgericht) towards what was then European Community law." ${ }^{136}$ Yet, in the So Lange II judgment, ${ }^{137}$ the German Constitutional Court-using the precise rhetoric of the "substance/essence/core"held, about an analogous issue, that so long as and in so far as the European communities generally safeguard the essential content of fundamental rights, it will no longer review the secondary Community legislation by the standard of the fundamental rights contained in the German Constitution.

A second expression of the idea of a hard core of fundamental rights can be found in the ECtHR case law addressing the EU principle of mutual trust. In the Avotins v. Latvia case, the ECtHR had to deal with the compatibility of the Convention with obligations under this principle requiring EU Member States to presume, save in exceptional circumstances, that other Member States respect fundamental rights. ${ }^{138}$ The ECtHR did not, at first sight, condemn this EU obligation, but nevertheless held that, under the ECHR, Member States "must at least be empowered to conduct a review commensurate with the gravity of any serious allegation of a violation of fundamental rights in the State of origin, in order to ensure that the protection of those rights is not manifestly deficient." 139 The case concerned the mutual recognition of a civil judgment imposed by the Regulation ${ }^{140}$. The Court thus underlined that a manifest deficiency in the protection of fundamental rights should entail an exception to the principle of mutual trust in EU law. Here also a distinction seems to be made between different types of violations of fundamental rights, which affects the intensity of Contracting parties' obligations under the Convention.

\section{The Essence of Fundamental Rights as a Criterion for Determining the Contracting Parties' Margin of Appreciation}

The distinction between the core and peripheral elements of rights has also been referred to by the Court in order to determine national authorities' margin of appreciation in several judgments.

\footnotetext{
${ }^{133}$ Michaud v. France, App. No. 12323/11 (Dec. 6, 2012), http://hudoc.echr.coe.int/eng?i=001-115377.

${ }^{134}$ Bosphorus, App. No. 45036/98 at para. 155 (emphasis added).

${ }^{135} \mathrm{~A}$ similar conclusion was already drawn earlier by J. Callewaert who observed that the judgment in $M$ \& Co App. No. 132558/87 (Jan. 9, 1990), which precedes Bosphorus, was largely inspired by the Solange judgement. See J. Callewaert, Les droits fondamentaux entre cours nationales et européennes, REVUE TRIMESTRIELLE DES DROITS DE L'HOMME 1190 (2001).

${ }^{136}$ Olivier De Schutter, Les deux vies de Bosphorus: la redéfinition des rapports entre la Cour européenne des droits de l'homme et les Parties à la Convention [The Two Lives of Bosphorus: Redefining the Relationships between the European Court of Human Rights and the Parties to the Convention], 2013 Journal EUROPÉEN DES DROITS DE L'HOMME [EUR. J. OF HUM. RTS.] 584, 588 (2013).

${ }^{137}$ Bundesverfassungsgericht [BVerfG] [Federal Constitutional Court] Oct. 1986, Re Wünsche Handelsgesellschaft, C.M.L.R. 339 (1987) (Ger.).

${ }^{138}$ Tony Marguery, Je t'aime moi non plus, the Avotinš v. Latvia Judgment: An Answer from the ECrtHR to the CJEU, $10 \mathrm{R}$. EUR. Admin. L. 113 (2017).

${ }^{139}$ Avotiņš v. Latvia, App. No. 17502/07, para. 114 (May 23, 2016), http://hudoc.echr.coe.int/eng?i=001-163114.

${ }^{140}$ Regulation (EU) No. 1215/2012 of the European Parliament and of the Council of 12 December 2012 on Jurisdiction and the Recognition and Enforcement of Judgments in Civil and Commercial Matters (Recast), 2012 O.J. (L 351) 1.
} 
As an illustration, the Court underlined in the Dudgeon case, concerning the criminalization of homosexuality in England, that although the margin of appreciation recognized to the national authorities could be extended where the protection of morals was in issue, the nature of the activities involved also affects the scope of the margin of appreciation. Yet, because the case at hand concerned, in the view of the Court, "a most intimate aspect of private life," the Court considered that "there must exist particularly serious reasons before interferences on the part of the public authorities can be legitimate for the purposes of paragraph 2 of Article 8." ${ }^{141}$ In the Hatton $v$. United Kingdom judgment, related to noise nuisance due to the permissive regime for night flights at London Heathrow Airport, the Court also considered that "where government policy ... interferes with a particularly intimate aspect of an individual's private life, the margin of appreciation left to the State will be reduced in scope." ${ }^{442}$

The semantic of the core/essence/substance doctrine in the margin of appreciation became more explicit in the joint dissenting opinion in Odièvre v. France related to the anonymous childbirth phenomenon where the Judges Bratza, Bonello, Loucaides, Cabral Barretto, Tulkens and Pellonpaa stressed that "certain aspects of the right to private life are peripheral to that right, whereas others form part of its inner core." They continued by affirming that they were "firmly of the opinion that the right to an identity, which is an essential condition of the right to autonomy and development, is within the inner core of the right to respect for one's private life." 143 The Judges consequently justified that "the fairest scrutiny was called for when weighing up the competing interests." ${ }^{144}$

Last but not least: One cannot overlook the explicit reference to the "core-periphery" distinction made by the ECtHR's judgment in R.M.T. v. United Kingdom ${ }^{145}$ with regard to the margin of appreciation conceded in cases concerning trade union freedoms. The Court ruled that, regarding Article 11 of the ECHR, which protects the freedom of association and the right to form or to join trade unions:

If a legislative restriction strikes at the core of trade-union activity, a lesser margin of appreciation is to be recognised to the national legislature and more is required to justify the proportionality of the resultant interference, in the general interest, with the exercise of trade-union freedom. Conversely, if it is not the core but a secondary or accessory aspect of trade-union activity that is affected, the margin is wider and the interference is, by its nature, more likely to be proportionate as far as its consequences for the exercise of trade-union freedom are concerned. ${ }^{146}$

\section{The Essence of Fundamental Rights as a Technique for Prioritizing Values: Critical Analysis}

The critical observations made in Section A and B can, mutatis mutandis, be transposed to these new elements. Here also, the existence of more important components of fundamental rights is postulated by the Court; here also the necessity to distinguish the essential from the incidental is

\footnotetext{
${ }^{141}$ Dudgeon v. United Kingdom, App. No. 7525/76, para. 52 (Oct. 22, 1981), =http://hudoc.echr.coe.int/eng?i=001-57473.

${ }^{142}$ Hatton v. United Kingdom, App. No. 36022/97, para. 10 (July 8, 2003) (emphasis added), http://hudoc.echr.coe.int/eng? $\mathrm{i}=001-61188$; K.A \& A.D v. Belgium, App. No. 42758/98, para. 84 (Feb. 17, 2005) http://hudoc.echr.coe.int/eng?i=001-68355 Criminal law cannot, in principle, intervene in the field of consenting sexual relations since it belongs the free will of individuals. There must therefore be 'particularly serious reasons' for public interference in the field of sexuality to be justified for the purposes of Article $8 \$ 2$ of the Convention.

${ }^{143}$ Odièvre v. France, App. No. 42326/98, para. 1 (Feb. 13, 2003) (Wildhaber, Bratza, Bonello, Loucaides, Cabral Barreto, Tulkens \& Pellonpää, JJ., dissenting) (emphasis added), http://hudoc.echr.coe.int/eng?i=001-60935.

${ }^{144} I d$. (emphasis added).

${ }^{145}$ R.M.T. v. United Kingdom, App. No. 31045/10, para. 87 (Apr. 8, 2014), http://hudoc.echr.coe.int/eng?i=001-142192. See also Tek Gida Is Sendikasi v. Turkey, App. No. 35009/05, para. 36 (Apr. 4, 2017), http://hudoc.echr.coe.int/eng?i=001-172858.

${ }^{146} I d$. (emphasis added).
} 
implied. But beyond these axiological affirmations, these categories are not defined in advance: It must indeed be observed that the case law of the EctHR does not provide satisfactory tools in order to identify the core from the periphery of fundamental rights.

It is, for example, in a piecemeal way that we learned that the strictly formal conception of the principle of adversarial proceedings, ${ }^{147}$ which was stated in the Vermeulen case, ${ }^{148}$ is ultimately not so "essential" for the ECtHR. Consequently, the absolute and explicit negation by the ECJ in its Emesa Sugar judgment ${ }^{149}$ does not constitute a "manifest deficiency" of Article 6 possibly entailing the rebuttal of the "Bosphorus presumption."

Moreover, if the distinction between more and less important elements of fundamental rights can be a prerequisite in a balancing of interests exercise or to determine the ambit of the margin of appreciation, ${ }^{151}$ the use of the "essence" rhetoric in this framework may nevertheless appear misguided. As underlined above, the traditional understanding of the essence/substance/core dimension implies a fundamental right's element is immune from any limitation, and, by way of consequence, from any application of the margin of appreciation doctrine. Yet, the use of this vocabulary in the framework of a weighing up reasoning conflicts with the classical notion of essence of fundamental rights and may thereby harm its intelligibility.

\section{E. Concluding Remarks}

"Like sugar in hot milk ..."

One cannot but observe the large dispersion of the notion of the "essence/substance/core" within the discourse of the ECHtR, and the versatility of the functions it fulfils. As an illustration, it is indeed the same word that is used by the Court in the judgments on Article 11 (freedom of association), in order to define this provision's scope of application-ratione materiae/schutzbereich ${ }^{152}$ - to determine the margin of discretion of national authorities, ${ }^{153}$ and apparently, to fix the "limit on the limits" that these authorities have to respect when they interfere with this freedom. ${ }^{154}$

There is no doubt that this dispersion and versatility do not make the understanding of the concept clearer and its credibility is, as a result, heavily undermined. The notion of the "essence/substance/core" of fundamental rights seems to be subject to an "overwork," and some parsimony in the use of this concept by the ECHtR would be more than welcomed. From this point of view, the separate dissenting opinions in the recent Regner ${ }^{155}$ and Naït-Liman ${ }^{156}$ cases opened the path to a welcomed critical move, both on the meaning of the concept and on its alleged functions.

The ECtHR, however, cannot be expected to fully resolve all the issues encompassed by the notion of the "essence/substance/core" of fundamental rights. Several arguments justify this pessimistic prediction. First, there is no reason that the Court of Strasbourg should succeed where other judges-investigating the respect of constitutional or conventional instruments enshrining

\footnotetext{
${ }^{147}$ On the difference between the formal and material conception of the principle of adversarial proceedings, see Frédéric Krenc \& Marie-Aude Beernaert, La Cour européenne des droits de l'homme à la recherche d'une conception pragmatique du procès équitable, in LES DROITS DE L'HOMME ET L'EFFICACITÉ DE LA JUSTICE 197-254 (2010).

${ }^{148}$ Vermeulen v. Belgium, App. No. 19075/91 (Feb. 20, 1996), http://hudoc.echr.coe.int/eng?i=001-57985.

${ }^{149}$ Case C-17/98, Emesa Sugar (Free Zone) NV v. Aruba, 2000 E.C.R. I-665 (Feb. 4, 2000).

${ }^{150}$ Cooperatieve Producentenorganisatie van de Nederlandse Kokkelvisserij U.A v. The Netherlands, App. No. 13645/05 (Jan. 20, 2009). See also Antoine Bailleux \& S. Van Drooghenbroeck, La Charte des droits fondamentaux-Invocabilité, interprétation, application et relations avec la CEDH, in LES INNOVATIONS DU TRAITÉ DE LISBONNE-INCIDENCES POUR LE PRATICIEN, 249-323. (Nicolas de Sadeleer, Hugues Dumont, Pierre Jadoul \& Sébastien Van Drooghenbroeck, eds., 2011).

${ }^{151}$ See, e.g., R.M.T., App. No. 31045/10.

${ }^{152}$ See Young, James \& Webster, App. Nos. 7601/76, 7806/77 at para. 65.

${ }^{153}$ See R.M.T., App. No. $31045 / 10$ at para. 87.

${ }^{154}$ See Rhino, App. No. 48848/07.

${ }^{155}$ Regner, App. No. 35289/11 (Serghides, J., dissenting; Sajó, J., partly dissenting).

${ }^{156}$ Naït-Liman, App. No. 51357/07 (Wojtyczek, J., partly dissenting).
} 
the intangibility of the essence of rights much more explicitly-continue to fail. In this respect, the "assessment" of the Swiss constitutional case law recently made by J. Dubey is no more promising than ours. ${ }^{157}$ In addition, and more fundamentally, we cannot but underline the frictions, if not the antinomy, existing between, on the one hand, the "reasoning paradigms" implied by the "essence/substance/core" of fundamental rights discourse, and on the other hand, the ECtHR's habits in terms of interpretation and application of the Convention. The concept of the "essence" indeed implies the ideas of unjustifiable per se of unconditional and absolute prohibitions-anytime, anyplace, and anywhere. The substance discourse entails the use of "always" and "never." Yet, the practical difficulties entailed by these concepts for the Court in Strasbourg, which simultaneously considers that the Convention is a "living instrument to be interpreted in the light of present-day living conditions," 158 are easily understandable. The ECtHR indeed firmly recognizes the necessity to sometimes call into question past considerations and to adapt conventional instruments to new and sometimes less favorable living conditions. ${ }^{159}$ Hence, is it credible to claim today that a particular legal measure impairs the essence of a right, whereas it was not the case a couple years ago, or vice versa? Can we seriously contend that such evolution is linked to a genuine transformation of the inherent nature of things, embodied by the rhetoric of the essence of rights, and not just to a matter of balancing interests in the framework of reasoning based on proportionality? Additionally, serious doubts may be expressed about the compatibility between, on the one hand, the "essence" rhetoric, with its always and never, and its pretentions to universality, and on the other hand, the cautious case-by-case approach advocated by the ECtHR—an analysis in concreto characterized by judicial minimalism).

Should we, for all that, mourn the idea of the intangibility of the essence of fundamental rights guaranteed by the Convention? Here is the paradox. As we previously stressed, this idea constitutes a regulating horizon for the entire ECHtR system. This is unavoidable and cannot be overlooked. But, however vital and logical, it remains fuzzy, elusive, and unable to provide the pragmatic tools of concrete reasoning.

"... [I]t is everywhere, but we can't see it. And, the more we search, the less we find it."

\footnotetext{
${ }^{157}$ JEAN DUbey, Droits FONDAMENTAux 219 (2017).

${ }^{158}$ Tyrer v. United Kingdom, App. No. 5856/72, para. 31 (Apr. 25, 1978), http://hudoc.echr.coe.int/eng?i=001-57587.

${ }^{159}$ See Sébastien Van Drooghenbroeck, Retour sur l'interprétation "involutive" de la Convention européenne des droits de l'homme, in LE DROIT MALGRÉ TOUT. HOMMAGE À FranÇOIS Ost 417-41 (2018).
} 